\title{
The Chittagong Hill Tracts Peace Accord in Bangladesh: An Overview
}

\author{
Helal Uddin Ahmmed \\ Lecturer, Department of International Relations \\ University of Chittagong, Bangladesh \\ Email: helal.ir.cu@gmail.com
}

\section{Md. Matiul Hoque Masud}

Lecturer, Department of International Relations University of Chittagong, Bangladesh Email: masud.ir.cu@gmail.com

Md. Faisal

Assistant Professor, Department of International Relations University of Chittagong, Bangladesh Email:callazim@yahoo.com

Md. Niaz Morshed

Lecturer, Department of International Relations University of Chittagong, Bangladesh Email: nmripon@yahoo.com

Doi: 10.5901/mjss.2013.v4n4p123

\section{Abstract}

The Chittagong Hill Tracts Peace Accord, signed on December 2, 1997 between the government of Bangladesh and the Parbattya Chattagram Jana Samhiti Samiti(PCJSS_Chittagong Hill People's Solidarity Association) ended a long-standing armed conflict between the Bangladesh Army and the tribal people of the Chittagong Hill Tracts in the south-eastern region of Bangladesh. The treaty promised to bring stability in the region. But 15 years into the signing of the Accord, it has yet to bear fruit. The region is still the most unstable region of the country and resentment among the tribal people is increasing day by day due to delays in the full implementation of the Accord. The Accord has also produced a new conflict: after its signing, a group emerged from within the PCJSS movement and formed the United People's Democratic Front (UPDF) a political party aiming at "full autonomy" rather than implementation of the Accord. The frequent clashes between PCJSS and UPDF and between the tribal and the 'Bengali Settlers' pose serious threat to the security of the country. In this situation this paper argues that the government of Bangladesh should take immediate and meaningful steps toward full implementation for the Accord. The costs of failure are high: disrupting activities, armed warfare, violations of human rights, losses of lives and resources, exposing the border regions to external threats-all of these are costs that the nation can hardly bear if lasting peace is not achieved.

Key Words: CHT, Autonomy, Peace Accord, Human Rights

\section{Introduction}

At various historical moments, almost every state has to face challenges posed by the divisive pulls of ethnicity, race, religion, and culture. The sharing of state power by the dominant groups has been the most contentious issue. In most of the cases, some kind of delegation of power and authority satisfies the group aspiring for power; occasionally, the demand for power sharing leads to a demand for autonomy, which if resisted transforms into demand for independent statehood (Chowdhury, 2002:1). Bangladesh's independence is an example of the latter phenomena. In the contemporary context of multinational states, Bangladesh enjoyed a unique advantage during its inception. It started its 
journey as an independent nation with a homogeneous population where less than $1 \%$ of its population is ethnically different and about four-fifths are Muslims. Bangla is practically the only language. But, Bangladesh had to face one of the most prolonged struggles for devolution of authority and autonomy, leading to a twenty-two-year armed insurgency by the tribal people of the Chittagong Hill Tracts.

The tribal people started a low-intensity guerrilla war in the early 1970s. But it was intensified after 1975, when the founding leader of the country, Bangabandhu Sheikh Mujibur Rahman, was assassinated and a military regime took power. The armed conflict continued up to the 1990s and it was only in 1997 that it formally ended with the signing of the Peace Accord. With the signing of the Accord, hope was renewed among the tribal people that they will eventually live in peace and dignity. But sixteen years into the signing of the treaty, many provisions remain unimplemented or partially implemented. This is creating a feeling of mistrust, fear and insecurity among the tribal people and thereby increasing the prospect of renewed armed insurgency in the region.

In this situation this paper offers several policy recommendations for achieving lasting peace in the region after examining the background to the signing of the Accord; its implementation status; assessment of its implementation to date and the current situation of the region.

\section{Historical Background to the Signing of the Accord}

The three hill districts of Rangamati, Khagrachari and Bandarban in the southeastern Bangladesh are collectively known as the Chittagong Hill Tracts (CHT). Bordering India and Myanmar, the CHT occupies about 10 per cent of the total land area of the country. It is a unique territory of Bangladesh with its diversity both in terms of landscape and its people. Prior to the 1950s, the region was inhabited mostly by the tribal people (Dasgupta \& Ahmed, 1998) who are significantly different from the mainstream population of the country in respect of race, language, culture and religion. They are of Sino-Tibetan descent belonging to Mongolian groups. Currently there are eleven ethnic groups in the CHT. Chakma, Marma and Tripura are the three principal groups. The other groups are Bawm, Chak, Khyang, Khumi, Lushai, Mro, Phangkhua, and Thangchangya. These tribal groups are collectively known as Jumma for their slash and burn style of agriculture, which is also known as 'Jhum' cultivation. Today, the Jumma people, numbering approximately 500,000, constitute about 53 percent of the total population of the $\mathrm{CHT}$.

The region was rule by the Mughal from 1666 until 1760. In 1760, it was ceded to the British East India Company. During the Mughal rule, the region was governed by non-formalized, somewhat independent, self-governance systems. The Mughal rulers did not interfere in the region's governance system in exchange of revenues. The British also followed the Moghal policy and the area was given the special status of an "autonomously administered" region by the Chittagong Hill Tracts Regulation of 1900. This regulation laid down specific rules on rights of entry and residence in the CHT and made it difficult for people from outside to acquire rights to land in the region. The Regulation also divided the CHT divided into three revenue circles, each headed by a rajah namely the Chakma Circle, the Mong Circle, and the Bohmang Circle. These circles were constituted with representatives from all tribes. The status of the CHT as a specially administered area was also recognized in the Government of India Acts of 1919 and 1935. The constitutions of Pakistan of 1956 and 1962 also retained the "special status". But, the "special status" was eliminated in 1963 through a constitutional amendment and by the mid-1960s, all local tribal employees in administration were transferred to other parts of East Pakistan (today's Bangladesh), making the local administration entirely staffed by Bengalis (Mohsin, 1997:46). In this period, the people of CHT also suffered a most devastating impact of 'modernization' and 'development', i.e. the construction of Kaptai Dam - a huge hydroelectric project on the Karnafuli River in Rangamati-that caused the displacement of over 100,000 Jumma people and flooded about 40 per cent of the region's arable land. Compensation for lost land was given but not in adequate amount and over 40,000 tribal people had to take permanent refuge in India (Amnesty International, 2000).

The independence of Bangladesh in 1971 was a curse for the Jumma people. During Bangladesh's War of Liberation (March 1971-December 1971), the Chakma Rajah supported the Pakistan army while the Mong Rajah joined the liberation force; the Bohmang Rajah remained non-committal. But, due to the decision of the Chakma Raja the Jumma people were branded as pro-Pakistanis. Therefore, the fury of the Mukti Bahini-the Liberation Force of Bangladesh-fell on the Jumma people: sixteen Jumma people were killed on December 5, 1971 and violence continued through the entire month of December (Ahsan \& Chakma, 1989:967). On 29 January 1972 a delegation of Jumma people met Sheikh Mujib and apprised him of the situation. But, Mujib argued that "such incidents are natural after a war" (Mohsin, 1997:57). The Jumma people could not accept Mujib's argument and took the situation into their own hands. The local youths recovered the arms left by Pakistan forces in the jungles of the $\mathrm{CHT}$, resisted the Bengalis and also set up an administrative system for the villages (Mohsin, 1997:57). 
The new state of Bangladesh moved towards the formulation of its Constitution. Considering their past experiences of exploitation and deep mistrust for the Bengalis, the Jumma people felt it necessary to have constitutional safeguards for their protection as a separate community. On 15 February 1972, a Jumma people's delegation led by Manobendra Narayan Larma met Sheikh Mujib and placed the several demands including the demands of autonomy for the CHT with its own legislature and imposition of a ban on the entry of non-tribal people into $\mathrm{CHT}$. As these demands were not accepted, Larma formed the Parbattya Chattagram Jana Samhiti Samiti (PCJSS). An armed wing-the Shanti Bahini (Peace Force)-was also added to it which started a guerrilla war against the government. As soon as armed clashes began, the government militarized the region by deploying 115,000 military personnel and in the 1980s the CHT was turned into a large military garrison. To counter the insurgency, the government also carried out a transmigration program which brought about 400,000 poor Bengali settlers in the region between 1979 and 1984 . The program significantly altered the demographic composition of the $\mathrm{CHT}$ as the percentage of Bengalis in the region rose from 26 per cent in 1974 to 41 per cent in 1981 (UNECOSOC, 2011:4).

The armed insurgency of the Jumma people continued up to the 1990s and during these years there were widespread and systematic violations of the human rights of the Jumma people in the region. During the period of insurgency, about 70,000 tribal people fled to India and around 100,000 people became internally displaced. The violence also caused ecosystem destruction, loss of biodiversity and natural resources degradation. The conflict formally ended with the signing of the Chittagong Hill Tracts Peace Accord between the government of Bangladesh and the PCJSS on 2 December 1997.

\section{The Peace Accord-Salient Features \& Implementation Status}

The Chittagong Hill Tracts Peace Accord is comprised of four parts-General, Hill District Local Government Council; the Chittagong Hill Tracts Regional Council; and Rehabilitation, General Amnesty and Other Issues. The Accord was implemented to some extent in the first couple of years, with the demobilization of PCJSS, repatriation of Jumma refugees, enactment of the three revised Hill District Council Acts and Regional Council Act, establishment of CHT Affairs Ministry and so on. But, the vast majority of the most important provisions of the Accord, such as withdrawal of temporary military camps, resolution of land conflicts and making functional the hill district councils and the regional council still remain unimplemented. In this part of the paper, we will examine the implementation status of the most important provisions of the peace Accord.

\section{General Provisions}

Clause A.1 of the CHT Peace Accord recognizes the necessity of protecting the character of this region while making provisions for its overall development. Toward this end, some legislative measures-for example, the Chittagong Hill Tracts Regional Council Act and the Chittagong Hill Tracts Land Disputes Resolution Commission Act of 2001-have been taken. However, the continued entry of non-tribal people into the region, the inclusion of Bengali settlers in the voter list, the issuance of permanent residence certificates to Bengali settlers, and other developments prove that the government authorities in the $\mathrm{CHT}$ and at the national level are still reluctant to preserve the characteristics of this region as a tribe-inhabited region.

Clause A.3 of peace Accord states that an implementation committee should be formed to monitor the implementation process. In 1998 a Committee was formed, but it existence was not maintained during the Bangladesh Nationalist Party (BNP) rule that lasted from 2001 until 2006. In May 2009, the current Awami League Government reconstituted the Committee and since then it has held only a few meetings.

\section{Chittagong Hill Tracts Local Government Council/ Hill District Councils}

In part B of the peace Accord the both parties agreed to "change, amend, add, and repeal the Hill District Local Government Council Acts of 1989" (Acts XIX, XX, XXI of 1989). These three acts established autonomous bodies known as Hill District Councils in the three districts of the CHT. According to these Acts, two-thirds of seats and the office of the chairperson of the Hill Districts Council are reserved for tribals. In Accordance with the Accord, the Hill District Council Acts were amended in 1998 whereby the councils were provided more authority than before. The 1989 District Council Acts provided delegation of 21 subjects to the hill district councils and Clause B.34 of the peace Accord added 12 subjects. But only 20 departments in 13 subjects had been delegated to the Hill District Councils to date. Clearly, many crucial matters have yet to be delegated under the authority of the councils. 
The Accord provides that the members of the District Councils will be elected by the permanent residents of CHT. But, no election has been held and the councils are being administered by government appointees. The disagreement over 'voter list' is the key obstacle to holding elections. As per the accord, only the 'permanent residents' of the region are eligible to be enlisted in the voter list. In Article B.3, the Accord defined 'permanent residents' as those who "have legal lands and specific addresses" in the region. A voter list was prepared before the 2001 parliamentary election, but was rejected by the PCJSS. They claimed that many 'settlers' (people who were brought to the region during the years of insurgency) had been included in the list. It seems that it is very difficult to prepare a well-accepted voter list since a large percentage of 'settlers' have land-ownership documents and hence could be included in new voter list.

\section{Chittagong Hill Tracts Regional Council}

Part $\mathrm{C}$ of the Accord provides for the establishment of a Regional Council, comprises of 22 members, including its Chairperson and reserves the office of the Chairperson with two-thirds of its seats for the Jumma people. According to the Accord, the members of the three Hill District Councils will elect the members of the Regional Council. Since no elections for the District Councils have been held, the current members of the Regional Council are all government appointees. The Accord provides the Regional Council with supervisory and coordinating authority over matters such as general administration, development activities, the District Councils, the CHT Development Board and customary law and social justice. It also has the right to advise the government on legislation concerning the region. But in practice the Regional Council has not been able to play its role effectively. Moreover, on 13 April 2010, the High Court declared the CHT Regional Council Act of 1998 unconstitutional stating that violated the sanctity of a unitary state (Manik \& Sarker, 2010). The government appealed the decision and the judgment was stayed by the Appellate Division pending hearing of the appeal.

\section{Rehabilitation, General Amnesty and Other Issues}

Repatriation and Rehabilitation of Refugees: Clause D.1 of the peace Accord provides that the approximately 70,000 Jumma refugees who fled to the Indian state of Tripura are to be repatriated on the basis of an agreement signed between the Bangladesh Government and the Jumma refugee leaders on March 9, 1997. In February 1998, about 64,609 Jumma refugees returned to their original homes and most of the facilities promised in the agreement were duly provided to them. However, there is allegation that about 9,700 families could not regain at least part of their original homes and lands since these had been occupied either by Bengali settlers or the military (UNECOSOC, 2011:13-14).

Rehabilitation of Internally Displaced Persons: Clause D.1 of the peace Accord states that the internal refugees of the region "will be rehabilitated through their proper identification by a task force". In line with the Accord, a task force was created but it became divided over the definition of internally displaced people. As a result, no rehabilitation measures could be undertaken. In 2000, the Task Force prepared a list which identified 90,208 tribal families and 38,156 Bengali families as internally displaced families and recommended a package program to resolve the problem. But, the list was rejected by the PCJSS and the Jumma Refugees Welfare Association because of the inclusion of Bengali settlers. The Task Force was reconstituted in 2009, but it still remains divided over the definition of internally displaced people. Thus, this clause of the Accord remains unimplemented to a large extent.

Resolution of Land Issues: Land dispute between the Jumma people and the Bengali settlers is the most crucial issue in the CHT. To resolve land related disputes, the Accord provides for the establishment of a Land Commission with the power of canceling leases of lands given to people other than tribal. In 1999, the first Chairperson of the Land Commission was appointed. But, it could not play its desired role during the years of BNP regime (2001-06) and the caretaker government of Fakruddin Ahmed (2007-09).

The work of the Commission is guided by the Accord and the Chittagong Hill Tracts Land Disputes Resolution Commission Act of 2001. There are several provisions in the Act that are inconsistent with the Accord. After the passing of the Act, the Regional Council proposed to amend some of its provisions (Roy \& Chakma, 2010:122). But the government took no necessary steps towards this. The issue of amendment has been one of the factors hindering the proper functioning of the Land Commission as the tribal members have refused start work until the removal of the inconsistencies between the Act and the provisions of the Accord. 
According to Clause D.2 of the Accord, a land survey would be carried out in $\mathrm{CHT}$ after determining land ownership and resolving all land related disputes. In August 2009, the current Land Commission announced that it will conduct a cadastral survey before the land disputes are settled. The Jumma people protested the decision and demanded to determine the land ownership first. After months of protests against the decision, the government cancelled the survey and declared that the survey will be conducted after determining the land ownership.

Clause D. 3 states that the government shall provide 2 acres of cultivable land or grove land to Jumma households that are landless or have less than 2 acres of land. The provision has not been implemented yet (Roy \& Chakma, 2010:85).

The Accord provides that land leases allotted to non-tribal or non-local people that were not properly utilized in the last ten years would be cancelled. In July 2009, the parliamentary committee on $\mathrm{CHT}$ affairs recommended to cancel the lease of more than 45,000 acres of land in the region. In August 2009, leases of 8,175 acres of land had been cancelled. But, the Jumma peoples are claiming that only a few leases have actually been cancelled.

General Amnesty \& Rehabilitation of PCJSS Members: Clauses D.13-16 of the accord are about general amnesty and rehabilitation of PCJSS members. These provisions of the peace Accord are in the state of full-implementation: about 683 PCJSS members were given jobs in the police and the government is providing monthly ration to 1,966 families. The government also provided 50,000 Taka in cash for each member as grant (Pinaki, 2011).

Demilitarization: Clause D.17 of the peace Accord states that "all temporary camps the Army, Ansar and Village Defense Party (VDP) excepting the BDR camps and the six permanent army establishments shall be withdrawn to permanent cantonments, and a timetable shall be set for this". By 2011, 235 camps have been withdrawn in phases since the Accord was signed ("Govt. to pull out army", 2011). But, the PCJSS claimed that out of more than 500 temporary military camps only 74 have been withdrawn to date. The government is yet to withdraw the de facto military rule 'Operation Uttaran' from the region by which military forces have been interfering into the civil administration and conducting military operation throughout the $\mathrm{CHT}$.

\section{Assessment of the Implementation Status of the Peace Accord and Its Effect on the Situation in the Region}

After fifteen years of the Accord it is clear that many important provisions such as the resolution of land disputes, withdrawal of temporary military camps and the devolution of authority to the local institutions are still remained unimplemented or only partly implemented. When the current Awami League government came to power on 6 January 2009, hope was renewed among the Jumma people regarding substantive progress in the implementation of the Accord. But despite continued assurance of the fullest implementation of the Accord, most of the crucial provisions still remain unimplemented.

One of the main reasons for non-implementation of the Accord is the highly polarized and divisive politics of the country. The Bangladesh Nationalist Party (BNP)—one of the two major political parties of Bangladesh-has been opposing the Accord since the very beginning and has been using the subject of the $\mathrm{CHT}$ to reap electoral benefits nationally. The fear of adverse electoral outcomes and the non-cooperative attitude of BNP have discouraged the Awami League from going for the fullest implementation of the Accord (UNECOSOC, 2011:15). Another reason behind the nonimplementation is the pervasive power and influence of the army over the Bangladeshi society. The army is one of the most powerful institutions in the country, often beyond public criticism or scrutiny, including by the Supreme Court. The army continues to oppose any substantive progress in the implementation of the Accord as it still believes in the Clausewitzian concept of victory as being the ultimate end state of all kinds of conflict. Hence, it is difficult for the army to view peace as the end state of the conflict in the $\mathrm{CHT}$ (Ahmed, 2011).

The state's failure to implement the Accord is increasing the prospect of renewed political instability and ethnic conflict in the region. The possibility of such outcomes is obvious from the occurrence of violent clashes between the Jumma people and the Bengali settlers in the region in recent years such as the 2010 Baghaihat incident in which at least three persons were killed and nearly 500 homesteads were burned down. There are allegations that members of the army were directly involved in the attacks on the Jumma peoples' home.

Other types of human rights violation are also taking place at an alarming rate. Violations include extrajudicial killings, arbitrary arrests, torture, and sexual harassment of the Jumma women. The delayed implementation of the Accord is also creating social instability in the region, as the PCJSS and the UPDF continue to fight among themselves to establish supremacy. About 50 activists these two groups of Jumma people were killed in clashes and more than 100 were kidnapped since the signing of the accord (Pinaki, 2011). 


\section{Policy Recommendations}

The present situation in the CHT proves that the peace Accord has failed in bringing peace in the region. The state's failure to implement all the provisions of the accord in a timely manner is leading to an increasing sense of frustration and disillusionment among the Jumma people which is enhancing the prospect of renewed armed insurgency in the region. And, if this frustrated people take up arms again, the effect will be devastating. Therefore, it is in the interest of the overall peace and security of the country that the present government should: (a) consider the matter as a critical national security issue and endeavor to build a nationwide consensus in favor of the treaty; (b) implement at least the provisions of resolution of land dispute, rehabilitation of internally displaced persons and demilitarization in the remaining period of its tenure; (c) create an independent commission that includes members from all parties in conflict to investigate the act of human rights violation and bring all the perpetrators under law and provide reparations to the victims; (d) impart legal services to the victims and provide one-stop support service to eradicate people's victimization in the region; and (e) promote social interaction between the Jumma people and the 'settlers', especially through sports and cultural activities.

\section{Conclusion}

The signing of the peace accord enkindled a light of hope among the Jumma people that they will eventually live in peace and dignity. But, their hope has not been materialized in the last fifteen years, as the state failed to implement most of the provisions of the Accord. Violent clashes between Jumma and Bengali people over land rights and the clashes between the PCJSS and UPDF for supremacy are still a daily affair in the region. The Jumma people expected that the present government of Sheikh Hasina-whose first government signed the Accord-will take steps toward full implementation of the Accord. But four years of this government have passed with no noteworthy measure. As a result, a feeling of mistrust, fear and insecurity among the Jumma people is growing day by day. Recently, the PCJSS Chairman Jyotindra Bodhipriya has expressed his frustration over delayed implementation and has threatened to launch tougher movements to see the treaty implemented. This news is not a good one for the overall peace and security of the country. It should be kept in mind that these people had once taken up arms and are likely to do so again if the promises made in the accord are not kept. Therefore, the government must take immediate steps for the fullest implementation of the Accord. The costs of failure will be high: disrupting activities, armed warfare, violations of human rights, losses of lives and resources, exposing the border regions to external threats-all of these are costs that the nation can hardly bear if lasting peace is not achieved in the Chittagong Hill Tracts.

\section{References}

Ahmed, A. F. L., (2011), "Peace in CHT: A Perspective on the Military Role", The Daily Star, URL: http://www.thedailystar.net/newDesign/news-details.php?nid=212731 (accessed on 06/12/2012).

Ahsan, S.A., \& Chakma, B. (1989) Problems of National Integration in Bangladesh: The Chittagong Hill Tracts. Asian Survey, 29(10), pp. 959-970

Amnesty International (2000), "Bangladesh: Human Rights in the Chittagong Hill Tracts", URL: $\quad$ http://www.amnesty.org/en/library/asset/ASA13/001/2000/en/a40d7d31-df83-11dd-8abb118b2e919ec0/asa130012000en.html (accessed on 10/12/2012).

"Coordinating body to reallocate lease-cancelled CHT lands" (2009), The Daily Star, URL: http://www.thedailystar.net/newDesign/latest_news.php?nid=18725 (accessed on 17/01/2013).

Chowdhury, B. H. (2002) "Building Lasting Peace: Issues of the Implementation of the Chittagong Hill Tracts Accord" Program in Arms Control, Disarmament, and International Security (ACDIS), University of Illinois at Urbana-Champaign. URL: http://acdis.illinois.edu/assets/docs/264/BuildingLastingPeacelssuesofthelmplementationoftheChittagongHillTractsAccord.p df (accessed on 01/12/2012).

Dasgupta, S. \& Ahmed, F.U., (1998): "Natural Resources Management by Tribal Community: a case study of Bangladesh", World Bank/WBI's CBNRM Initiative, URL: http://srdis.ciesin.org/cases/bangladesh-002.html (accessed on 01/12/2012).

"Govt. to pull out army from CHT: Says CHT affairs secretary" (2011), The Daily Star, URL: http://www.thedailystar.net/newDesign/print_news.php?nid=212546 (Accessed on 29/12/2012).

Levene, M (1999), "The Chittagong Hill Tracts: A Study in the Political Economy of 'Creeping' Genocide", Third World Quarterly, 20(2), pp. 339-69.

Manik, J. A \& Sarker, A. (2010), "Decade-old hills admin at stake", The Daily Star, URL: http://www.thedailystar.net/newDesign/newsdetails.php?nid=134324 (accessed on 01/12/2012).

Mohsin, A. (1997), The Politics of Nationalism: The Case of the Chittagong Hill Tracts (Dhaka: The University Press Limited). 
Pinaki Roy (2011), "A hill of let-down", The Daily Star, URL: http://www.thedailystar.net/newDesign/news-details.php?nid=212697 (accessed on 06/12/2012).

Rahman, M. A. (2005), "Chittagong Hill Tracts Peace Accord in Bangladesh: Reconciling the Issues of Human Rights, Indigenous Rights and Environmental Governance. Journal of Bangladesh Studies, 7(1), pp. 46-58.

Roy, R. D. (2009), "The ILO Convention on Indigenous and Tribal Populations, 1957 (No. 107) and the Laws of Bangladesh: A Comparative Review", International Labour Organization, Switzerland.

Roy, R. D. \& Chakma P. (2010), "The Chittagong Hill Tracts Accord \& Provisions on Lands, Territories, Resources and Customary Law", in Victoria Tauli Corpuz et al. (eds.), Hope and Despair: Indigenous Jumma Peoples Speak on the Chittagong Hill Tracts Peace Accord (Baguio City: Tebtebba Foundation, pp. 115-176), URL: http://tebtebba.org/index.php/all-resources/category/8books?download=32:hope-and-despair-indigenous-iumma-peoples-speak-on-the-cht-peace-accord (accessed 09/11/2012).

United Nations Economic and Social Council (UNECOSOC) (2011), "Study on the status of Implementation of the Chittagong Hill Tracts Accord of 1997", URL: http://www.unhcr.org/refworld/docid/4dbfb1262.html (accessed on 09/11/2012). 
